\title{
Salvação integral na América Latina: breve ensaio bíblico-teológico a partir da Teologia da Missão Integral
}

\author{
Integral salvation in Latin America: brief biblical- \\ theological essay from Theology of Integral Mission
}

\section{Salvación integral en la América Latina: breve ensayo bíblico-teológico desde la Teología de la Misión Integral}

Sidney Moraes Sanches*

\author{
Tudo tem surgido pela fala, \\ E nossos grandes fracassos são por não falar, \\ Tudo o que nós precisamos fazer, é estar \\ seguros de que continuaremos conversando. ${ }^{1}$
}

\begin{abstract}
RESUMO
A Salvação é a palavra que anima a prática evangelizadora e pastoral das igrejas evangélicas na América Latina, particularmente, no Brasil. Portanto, é crucial o entendimento do seu significado. Primeiro, introduziremos a maneira como a salvação é representada nos textos bíblicos como a provisão da parte de Deus de um shalom para a sua criação. Depois, indagaremos como a Teologia da Missão Integral aborda a salvação na América Latina em resposta às condições reais de vida de seus povos. Por fim, atualizaremos esse esforço da Teologia da Missão Integral, discorrendo sobre como falar de salvação com a imagem bíblica de shalom, a partir de uma Soteriologia narrativa contextualmente latino-americana.

Palavras-chave: Salvação; shalom; América Latina; teologia da missão integral; soteriologia narrativa.
\end{abstract}

\begin{abstract}
Salvation is the word that stimulates the evangelizing and pastoral practice of the evangelical churches in Latin America, particularly at Brazil. Hence, the understanding of his meaning is very essential. First, we will to introduce the manner how salvation is represented in biblical texts as a supply from God of a shalom to his creation. After, we will enquire how Theology of Integral Mission approaches the salvation in the Latin America in response to real conditions of people's life. Lastly, we will update this effort of Theology of Integral Mission, discussing about how to speak of salvation with the biblical image of shalom, from a narrative Soteriology contextually Latin American.

Key-words: Salvation; shalom; Latin America; theology of integral mission; narrative soteriology.
\end{abstract}

Doutor em Teologia pela Faculdade Jesuíta de Filosofia e Teologia (FAJE) e Pós-doutorando na FAJE, bolsista CAPES, 2017/2018.

Talkin' Hawing': Speech has allowed the communication of ideas / Enabling human beings to work together / To build the impossible / Mankind's greatest achievements / Have come about by talking / And its greatest failures by not talking / Our greatest hopes could become reality in the future / With the technology at our disposal / The possibilities are unbounded / All we need to do is make sure we keep talking. 


\section{RESUMEN}

Salvación es la palabra que anima la práctica evangelizadora e pastoral de las iglesias evangélicas en América. Latina. Por consiguiente, es crucial lo entendimiento de su significado. Primero, introduciremos la manera como la salvación es representada em los textos bíblicos, como la provisión de Dios de un shalom para la suya creación. Después, indagaremos como la Teología de la Misión Integral aborda la salvación en América Latina em respuesta a las condiciones reales de vida de sus pueblos. Por fin, actualizaremos ese esfuerzo de la Teología de la Misión Integral, discurriendo sobre como hablar de salvación con la imagen bíblica del shalom, a partir de una Soteriología narrativa contextualmente latinoamericana.

Palabras-clave: Salvación; shalom; América Latina; teología de la misión integral; soteriología narrativa.

\section{Introdução}

Não há algo a ocupar, mais intensamente, o pensamento e a prática evangelizadora e pastoral de igrejas evangélicas na América Latina e no Brasil do que a salvação, em seus muitos usos semânticos. Ela é a mais evangélica das palavras cristãs que se pode enunciar em qualquer lugar, na América Latina e, particularmente, no Brasil. Para as igrejas evangélicas, a salvação chegou até aqui pelo trabalho de missionários e missionárias protestantes que, como proclamadores cristãos da salvação, percorreram o planeta, incontáveis vezes, para levá-la a todas as nações da terra. E também o fizeram na América Latina e no Brasil. Até nós, chegou a palavra de salvação. E ela prossegue, como herança do empreendimento missionário evangélico, sendo anunciada todos os dias, e com impetuosidade ainda maior, graças aos meios de comunicação e ao crescimento das igrejas evangélicas dedicadas com afinco a essa tarefa.

Sobre a salvação, faremos um delineamento geral, sucinto e breve. Em um primeiro momento, perguntamos pela maneira como a salvação é representada nos textos bíblicos. E responderemos com a provisão da parte de Deus de um shalom para a sua criação, um lugar de delícia, felicidade e paz. A partir dele, veremos os textos bíblicos das origens, que fazem a leitura das condições humanas que não correspondem a esse ideal. O modo como Deus age para que ele se torne realidade é chamado, então, "salvação".

Em um momento seguinte, nos fixamos no surgimento, na segunda metade do século XX, da renovação do pensamento protestante sobre a salvação, produzida nos dois organismos ecumênicos principais: O Conselho Mundial de Igrejas (CMI) e a Aliança Evangélica Mundial (AEM). Isto será necessário para que, depois, penetremos no esforço autóctone e contextual de teólogos evangélicos latino-americanos em aproximar a salvação da realidade concreta dos povos da América Latina. Tal pensamento compreende que a salvação carece de um contexto histórico-social-cultural, caso contrário, ela é somente a redescrição de outra realidade, aquela das nações protestantes colonizadoras. Faremos isso com a ajuda do teólogo batista porto-riquenho Orlando E. Costas. 
O último momento atualiza esse esforço teológico de pensar a salvação para dentro e para fora, para aqui e para depois, da realidade concreta da América Latina, em duas direções. A primeira, conectando a imagem bíblica de salvação - shalom com a salvação de que carece a América Latina. A segunda, sugerindo uma Soteriologia narrativa que consiste em uma narrativa aumentada dessa imagem bíblica.

\section{Shalom como palavra/símbolo/imagem/metáfora/parábola bí- blica de salvação}

A palavra salvação não possui significado único e uso unânime, nem na língua portuguesa e, muito menos, nas Escrituras judaicas (Bíblia hebraica e grega - ou Septuaginta) e cristãs (Novo Testamento). Nesses textos, salvação aponta para a condição humana carente de ajuda, que pede socorro, cujo resultado é uma nova condição humana de bem-estar ou felicidade, representada na palavra/ símbolo/imagem/metáfora/parábola bíblica shalom (BAUER, 2000, p. 360).

Toda palavra é símbolo. Um símbolo não se esgota em si mesmo, a não ser em relação com outros símbolos, formando um conjunto complexo. Eles são signos reportando-se uns aos outros e aos objetos aos quais pretendem significar. É a compreensão dessa correta inter-relação que se torna matéria da sua interpretação. Esse conjunto simbólico, por sua vez, reflete ou pressupõe determinado(s) contexto(s) aos quais os símbolos querem referir (NEVILLE, 2001). ${ }^{2}$

Portanto, a interpretação de uma palavra/símbolo é realizada desde dentro e a partir de sistemas simbólicos. O que requer um caráter triádico: o signo, seu objeto e a interpretação que procura associar ambos entre si a partir de um contexto. Esta, então, coloca a tríplice problemática para uma teoria da interpretação do símbolo: a sua definição, a natureza da sua referência e o significado do seu contexto interpretativo.

Uma palavra/símbolo é imagem esquematizada da realidade, e não conceito construído abstrata ou metafisicamente. É certo que dela se tem abstraído um discurso teológico que procura descrever, conceituar, definir, extrair uma teoria geral e ampla da realidade. Esse discurso é oferecido logicamente às pessoas na forma de um sistema de crenças, substituindo e removendo o símbolo da sua experiência imediata.

\footnotetext{
2 Segundo Neville (p. 1-23, 60-92), os símbolos constituem superestruturas semióticas que permitem interpretar toda a existência humana, inclusive a religiosa. Os símbolos religiosos, portanto, são sistemas simbólicos, com funções de referência primária, o que eles indicam, e secundária, a apropriação pessoal que se faz deles, e dependentes sempre de um contexto para interpretá-los. Confira, também: HAIGHT, 2004, p.149-187. As considerações seguintes seguem a teoria dos símbolos religiosos proposta por ambos.
} 
Ao fazê-lo, perde-se o apelo mais fundamental do símbolo, que é a participação ou envolvimento existencial do intérprete no objeto que ele significa. Os conceitos metafísicos podem ser manuseados à distância, enquanto que o símbolo requer um engajamento pessoal imediato. Segundo Robert C. Neville:

as pessoas se envolvem com as realidades últimas diretamente através de símbolos, não indiretamente, como se os conceitos teológicos fossem os signos reais para o envolvimento e os símbolos fossem representação dessas concepções, não o próprio objeto delas. Certos aspectos de Deus e de outras questões últimas podem certamente ser percebidos através do envolvimento com conceitos teológicos. Mas, a maioria das questões existencialmente importantes a compreender sobre Deus só podem ser obtidas por meio de imagens esquematizadas dos símbolos religiosos (NEVILLE, 1999, p. 2). ${ }^{3}$

Símbolo e metáfora evocam, a princípio, campos diferentes de significado, segundo reconhece Paul Ricoeur (1975). ${ }^{4}$ O símbolo trabalha sempre com um excesso de sentido do significado primário ou literal de um vocábulo, uma espécie de sentido do sentido. Ele não possui autonomia linguística, pois sua atividade é corresponder a uma certa configuração estabelecida. Ao contrário, a metáfora é uma invenção livre do discurso. Por outro lado, uma vez assimilada no discurso a metáfora morre, enquanto que o símbolo jamais morre, porém se transforma.

É exatamente acerca da experiência do ser humano no e com o mundo, e para a sua compreensão dele, que a metáfora oferece uma estrutura conceitual, ou esquema imagético adquirido a partir das relações humanas com o ambiente físico. O conhecimento obtido por meio dessas relações é guardado na memória, permitindo a construção de modelos mentais ou cognitivos, por meio dos quais se pode mapear ou delinear a realidade por meio de expressões linguísticas. A metáfora, assim, é:

[...] o mapeamento de dois conceitos pertencentes a domínios diferentes do conhecimento. Como resultado deste mapeamento, um conceito (o alvo) é estruturado (entendido) em termos do outro (a fonte) [...] a cognitividade repousa na estrutura conceitual subjacente à nossa abordagem da realidade, e não em uma presumida determinada relação entre ordem lógica e ontológica (como na abordagem objetivista). O conhecimento não espelha a realidade, mas é localizado na organização de nossa abordagem à realidade (FEYAERTS, 2003, p. 19).

Cf. HAIGHT, 2003, p. 18-27.

4 Cf. HAIGHT, 2003, p. 23-30. Segundo Haight: "a idéia de um símbolo é essencialmente tensiva, dinâmica e dialética; um símbolo medeia alguma outra coisa que não ele próprio, induzindo ou remetendo a uma verdade mais profunda ou mais elevada que se encontra para além de si mesmo". Símbolo se distingue de Metáfora, enquanto esta é conceitual ou consciente, e aquele é concreto, um objeto. 
Uma metáfora pode se constituir em uma narrativa, isto é, em uma parábola. Esta evoca certos símbolos profundos da experiência humana, enquanto também articula uma linguagem que narra metaforicamente essa experiência.

Paul Ricoeur (2001) diz que uma parábola é uma conjunção de uma forma narrativa e de um processo metafórico. Isso equivale a dizer que chamar uma narrativa de parábola significa que ela se refere a algo que é diferente daquilo que é dito; e descrevê-la como metafórica é afirmar que a narrativa exerce uma função expansiva desse significado. Ela é uma fonte cujo significado tem por alvo representar outra realidade. Uma parábola, ao se reportar a determinados símbolos, tem o poder de redescrever a experiência humana, sua referência fundamental, centrada ao redor de experiências-limites, correspondentes a expressões-limites da linguagem religiosa, que exigem a mediação de conceitos-limites típicos da linguagem teológica.

Voltemos para nossa imagem bíblica de salvação como shalom. O fato de seu conteúdo semântico não ser traduzível em nenhuma língua à parte da palavra mesma mostra que sua função é totalmente simbólica, e que somente é inteligível se remetida a outros sistemas simbólicos, todos, por sua vez, inseridos na linguagem simbólica maior de salvação.

A interpretação de shalom, no texto bíblico, requer uma definição, uma referência e um contexto de interpretação do intérprete. Pode-se dizer que shalom indicava a paz resultante do bem-estar completo que dá à vida sua qualidade de perfeitamente vivida (BROWN, 1983, p. 473). Qual seria a referência imediata de shalom? A vida, em seus sinais de vitalidade, energia e força, experimentada em suas realizações cotidianas, comuns a cada ser humano, celebrada em manifestações de gratidão, como na fé comunitária do povo israelita, em aliança com o Senhor/Iavé, doador da própria shalom. O contexto interpretativo ou a referência secundária, estava, claramente, na posse da terra e na aliança com o Senhor/Iavé como lugar de vida e sua longevidade.

Vê que proponho, hoje, a vida e o bem, [...] escolhe, pois, a vida, para que vivas, tu e a tua descendência, amando o Senhor, teu Deus, dando ouvidos à sua voz e apegando-te a ele, pois disto depende a tua vida e a tua longevidade (Deuteronômio 30, 15; 19; 20).

Foi a experiência concreta das tribos e clãs israelitas, após a conquista e assentamento na terra de Canaã, ainda que de modo tão ideal.

Desta maneira, deu o Senhor a Israel toda a terra que jurara dar a seus pais; e a possuíram e habitaram nela. O Senhor lhes deu repouso em redor, segundo tudo quanto jurara a seus pais; nenhum de todos os seus inimigos resistiu diante deles; a todos eles o Senhor lhes entregou nas mãos. Nenhuma promessa falhou de todas as boas palavras que o Senhor falara à casa de Israel; tudo se cumpriu (Josué 21,43-45). 
Essa experiência não estava separada da vivência social e política, antes, a englobava como parte da aliança com o Senhor/Iavé. Desse modo, era comum associar o shalom à verdade e à justiça em seu pleno exercício: "Ah! Se tivesses dado ouvidos aos meus mandamentos! Então, seria a tua paz como um rio, e a tua justiça, como as ondas do mar" (Isaías 48,18).

Não separada dessa referência e contexto, shalom é imagem e metáfora da salvação. No Salmo 85, a retirada da salvação é associada com a indignação e ira de Deus contra o povo de sua aliança (1-6). Em contrapartida, ele pede que o Senhor/Iavé restaure a sua salvação e esta envolve a doação de shalom para o povo $(7,8)$. Esta é representada na seguinte sequência:

Encontraram-se a graça e a verdade, a justiça e paz se beijaram. Da terra brota a verdade, dos céus a justiça baixa o seu olhar. Também o Senhor dará o que é bom, e a nossa terra produzirá o seu fruto. A justiça irá adiante dele, cujas pegadas ela transforma em caminhos (10-13).

Essa metáfora de salvação, unida a um formato narrativo, constitui uma parábola de salvação. Pensemos na parábola da desorientação humana em Gênesis, capítulo 3. A ajuda era necessária ante uma situação humana de profunda aflição, seja individual, seja comunitária. O socorro escapava ao indivíduo e seu grupo. E é a Deus que se apelava para salvar ou socorrer, portanto, ele era o salvador. Com o passar do tempo, os textos escriturísticos foram acumulando situações ou eventos humanos mais complexos e a salvação foi se ampliando para a situação humana em um universo caótico, onde o lugar em que se vivia era cada vez mais experimentado como opressivo, e a desorientação histórica esvaziava qualquer expectativa de um fim feliz.

Agora, voltemos para Gênesis, capítulos 1 e 2. Esse final feliz é narrado como um shalom, uma situação de pleno bem-estar resultante de uma cabal comunhão do ser humano consigo mesmo, com o mundo e a criação ao seu redor, naturalmente provido por e com Deus, a própria fonte criadora de todo bem e felicidade humana. Salvação é recuperação, reprodução, revisitação desse shalom, aqui e agora. Ele é o alvo da vida humana, inteiramente dependente, como ela é, da corporeidade, da vida que se vive debaixo do Sol.

No contexto neotestamentário, Jesus Cristo tanto é Mediador da salvação (sotêria) quanto da paz (eirènè, shalom). As duas estão reunidas nele. Ele traz consigo mesmo um conjunto de expectativas de salvação que foram se acumulando na medida em que se prolongava a história israelita na terra. Estas se ligam às suas obras e à sua oferta de salvação agrupadas no seu ensino acerca do Reinado de Deus, equivalente ao shalom. As longas unidades narrativas da paixão de Jesus Cristo, inclusive sua crucificação, encontram seu 
nexo e, portanto, significado, na referência à sua vida e obra, e enfim, sua missão. Esta consiste em introduzir o shalom na vida humana vivida sobre a terra, e fazer entrar os seres humanos neste shalom.

\begin{abstract}
Bem-aventurado aquele que comer pão no reino de Deus. Ele, porém, respondeu: Certo homem deu uma grande ceia e convidou muitos. À hora da ceia, enviou o seu servo para avisar aos convidados: Vinde, porque tudo já está preparado. [...] Sai depressa para as ruas e becos da cidade e traze para aqui os pobres, os aleijados, os cegos e os coxos. Depois, lhe disse o servo: Senhor, feito está como mandaste, e ainda há lugar. Respondeu-lhe o Senhor: Sai pelos caminhos e atalhos e obriga a todos a entrar, para que fique cheia a minha casa (Lucas 14,15-24).
\end{abstract}

Paulo atualizou esse uso de salvação enquanto shalom para o mundo helênico. À vontade de Deus em ofertá-la aos seres humanos, ele chamou graça. Não existe salvação sem plena doação que chama para uma vida de gratidão, de gozo, de satisfação consigo mesmo, com os outros e com a criação, na qual se experimenta gratuidade, equivalente ao shalom para o qual todos os povos são chamados à acolhida e participação.

Todos os movimentos reformadores compartilharam a ideia paulina quanto à salvação. Todas as reformas, notadamente as protestantes do século XVI, foram desencadeadas de experiências pessoais insatisfatórias sobre como a fé cristã respondia às suas ansiedades por salvação, e a busca por uma salvação mais contente que os reintroduzisse em uma situação de pleno bem-estar. Essa condição é possível pela justificação pela fé, que chama os seres humanos à acolhida e participação no shalom.

Conforme afirma Timothy George:

A doutrina da justificação pela fé pressupõe a apropriação subjetiva do dom divino da salvação, mas também reconhece que mesmo aquela fé pela qual somos justificados é, em si mesma, semelhantemente um dom (GEORGE, 1994, p. 308).

Nesse contexto evangélico, fala-se bastante do dom ou da dádiva da salvação. Mas, o que é um dom ou dádiva? É algo que pertence ao doador, aquele que dá. No momento em que ele o transfere para outrem, aquele que recebe, o dom já não é mais seu, mas daquele que o recebeu. Existe uma troca de posse. É nesse momento que a liberalidade, no dizer de Aristóteles, ou a generosidade, no nosso dizer, se expressa por inteiro na relação entre Deus e os seres humanos. E a manifestação desta é o dom ou a dádiva.

Claro que o dom não é dom caso não seja assim entendido por quem dá e por quem recebe. O que faz de algo ser um dom? Não seria a relação 
que se estabelece antes entre o doador e o recebedor do dom, marcada, sobretudo, pela generosidade do doador e pela gratidão e louvor do recebedor? No final do processo de troca do dom, não é o dom que terá o valor maior, pois ele pode se dissipar com o tempo e o uso. $\mathrm{O}$ que fica é a generosidade demonstrada pela qual aquele que a recebe sempre poderá lembrar, narrar e louvar a quem lhe deu.

É por isso que o dom é sempre descrito, nos antigos textos judaicos e cristãos, reunidos na Bíblia, como uma bênção, e o ato de generosidade, como abençoar. Segundo eles, o maior abençoador é Deus, de longe o mais generoso. Como Deus abençoa sua criação, os seres humanos também participam dessa bênção. Conforme aqueles textos, o dom maior que Deus distribui generosamente é a vida. Se o ser humano deseja ser igualmente generoso como Deus é, a melhor maneira de fazê-lo é distribuindo, liberalmente, a vida. Dom e dádiva criam e recriam o shalom de Deus, portanto, a salvação.

Deve-se, igualmente, pensar no dom e na dádiva como aquilo que iguala as pessoas, isto é, fazendo que, quem possui muito, não seja tão superior a alguém que possui menos. Quando aquela dá do muito que tem, ficará com menos, mas, aquela que recebe, esta terá um pouco mais do que possui. Se entendêssemos, realmente, a salvação enquanto um shalom, não deveria haver pessoas passando necessidades e outras com sobras, pois haveria igualdade de recursos entre elas. Se uma pessoa tem demais, deve repartir com outra que está em necessidade. Assim, as pessoas teriam as mesmas condições e poderiam se socorrer mutuamente. E se poderia falar de salvação, de shalom entre as pessoas.

Também se deve pensar na questão importante de receber corretamente a generosidade de alguém. Há aqueles que sabem apenas ser generosos, mas não sabem receber a generosidade. Enquanto generosos, podem alardear suas boas ações. Enquanto recebedores da generosidade, precisam reconhecer que dependeram ou precisaram da generosidade de alguém, algum dia. Enquanto pessoas generosas, são louvadas por aqueles a quem beneficiaram. Mas não sabem ou não querem louvar aqueles que as beneficiam. Há outro nome para as pessoas que não querem a generosidade dos demais: orgulhosas.

O espaço do shalom, que é a salvação judaico-cristã, se faz quando se reconhece a Deus, o Senhor de toda a vida, como o Doador dessa vida que, sendo sua, ele a dá ou doa a tudo e a todos. É sua grande dádiva. Quando o ser humano a recebe, graciosamente, faz-se agradecido e sua gratidão o faz generoso e liberal, chamando e introduzindo a outros e outras na mesma experiência de vida. Esse é o Evangelho e esta é a salvação. Forma-se um círculo virtuoso, no dizer de Comte-Sponville: 
[...] a generosidade, como todas as virtudes, é plural, tanto em seu conteúdo como nos nomes que lhe prestamos ou que servem para designá-la. Somada à coragem, pode ser heroísmo. Somada à justiça, faz-se equidade. Somada à compaixão, torna-se benevolência. Somada à misericórdia, vira indulgência. Mas seu mais belo nome é seu segredo, que todos conhecem: somada à doçura, ela se chama bondade (COMTE-SPONVILLE, 1999, p. 113).

\section{Salvação nos Protestantismos contemporâneos}

Os "missionarismos" protestantes em todo o mundo fizeram da justificação pela fé o centro de sua mensagem de salvação, inclusive na América Latina. Todavia, esta foi continuamente influenciada pelas condições dos tempos, visto que a salvação, no protestantismo, parte da angústia do tempo para se fazer resposta a ela. Portanto, uma análise dos tempos sempre foi fundamental aos protestantismos, quando se trata de anunciar a sua salvação ao mundo. Isto implica que nem sempre a mensagem de salvação correspondeu ao uso bíblico de salvação e sua apresentação protestante da justificação pela fé.

$\mathrm{Na}$ segunda metade do século passado, período de aglutinação de forças globais na nova conformação geopolítica do mundo pós-guerra e pós-colonização, também os protestantismos responderam com a constituição de duas grandes forças: o movimento ecumênico representado no Conselho Mundial de Igrejas (CMI), e a reunião dos evangélicos discordantes na Aliança ou Fraternidade Evangélica Mundial (WEF). Ambos os agrupamentos passaram a insuflar formas e modos de perceber a angústia do tempo e formular o modo como a mensagem protestante de salvação deveria ser para atender a ela.

\section{Salvação nos Protestantismos do Conselho Mundial de Igrejas}

Dentro do CMI, há um importante documento elaborado sob o patrocínio da Comissão de Evangelismo e Missão Mundial, reunida em Bangkok, Tailândia, entre 29/12/72 e 09/01/73, discutindo o tema: Salvação Hoje. Este documento foi dividido nos seguintes subtemas: "Cultura e identidade". "Salvação e justiça social". "As igrejas renovadas em missão". É sinal dos tempos, que esse evento tenha se dado no extremo Oriente, em um país tradicionalmente budista, onde os cristianismos de qualquer espécie jamais conseguiram um estabelecimento profundo na cultura e no povo tailandês. A razão para o não acolhimento estaria no povo e sua cultura, ou na sua apresentação, ou mesmo em seu conteúdo? Não seria o caso de se interpretar a mensagem de salvação de modo que fosse acolhida? 
O bispo metodista uruguaio Mortimer Arias adaptou a temática da salvação, tratada no congresso, para o contexto da América Latina, na pequena obra: Salvação Hoje, publicada no Brasil pela editora católica Vozes, em 1973. Significativo é o título em castelhano: La Salvación Hoy: entre la cautividad y la liberación. Dá exatamente a dimensão de como anunciar a salvação naqueles anos de 1970: a libertação de um cativeiro, sem a qual não seria possível a salvação.

O primeiro capítulo da obra se chama "A busca de salvação e a experiência contemporânea". Responde ao título do livro: Salvação hoje. Ambas as temáticas pressupõem que existe uma carência de salvação mesmo na modernidade atual. Ela apenas é colocada de maneiras diferentes e, por vezes, de maneiras que a visão tradicional de salvação que nós, protestantes, herdamos, não consegue nem detectar, nem atender. Nas palavras de Arias:

A busca contemporânea, entretanto, está marcada por novas perspectivas e preocupações. O homem tomou consciência de sua dimensão histórica, saiu de sua província geográfica para o universo espacial. Descobriu seus direitos de homem e reclama sua plena vigência. Preocupa-se não somente com seu destino individual, mas também com o destino da própria humanidade. Descobriu suas potencialidades criadoras e inventou engenhosos e complicados instrumentos para dominar o mundo e colocá-lo a seu serviço. Por outro lado, começa também a tomar consciência de suas limitações, de seus imponderáveis, dos riscos da História. Deve fazer frente a sistemas brutalmente repressivos ou a preconceitos profundamente arraigados, que regem seu lugar a emergentes minorias e postergadas maiorias. Precisa adaptar-se a normas e valores da "grande sociedade" que escapam ao controle do indivíduo e permeiam toda sua existência, ameaçando a própria privacidade do pensamento. A busca de salvação assume, então, novos e desorientadores acentos e reveste-se de cores novas de esperança (ARIAS, 1973, p. 12).

A conclusão de Arias é que essas questões colocam maneiras diferentes e desafiadoras à igreja no que diz respeito ao modo como ela dará testemunho da salvação, hoje. Trata-se de responder às perguntas:

Qual é o conteúdo da salvação cristã, hoje? Qual é o propósito de Deus para a vida humana? Que relação tem a prática histórica com esses propósitos de Deus e, portanto, com a salvação? Teremos entendido a mensagem bíblica da salvação em toda a sua integridade? Que agentes Deus usa na História, além da Igreja? Que significado têm as lutas humanas de hoje pela dignidade, liberdade, identidade, libertação das opressões econômicas, políticas e sociais? É a salvação de Deus algo puramente individual ou escatológico ou é também social e histórica? Como se expressa a fé do cristão na prática histórica? Como se relacionam os cristãos com as aspirações, lutas, agonias e esperanças de nossos povos? (ARIAS, 1973, p. 18). 
Um resumo das respostas a essas perguntas pode ser: A salvação é a mensagem central da fé cristã. Para os cristãos, ela acontece por meio de Jesus Cristo. A salvação de Deus se realiza na História. As lutas históricas humanas podem ser interpretadas como salvação. Deus agiu e continua agindo para a salvação dos seres humanos.

Arias, depois, fala sobre a totalidade da salvação. Esta se desdobra a partir de um centro ao redor de quatro dimensões. Este centro é a boa vontade de Deus em salvar o ser humano reconciliando-o consigo mesmo. Passagens bíblicas como: 1 Timóteo 2,4-5; João 3,16; 14,6; Romanos 3,23; Atos 4,12, mostram que Deus proveu o caminho para a salvação, e que esta se realiza desde um diagnóstico da condição humana pecaminosa e de um único mediador da salvação: Jesus Cristo.

Porém, uma salvação total será tanto material quanto espiritual. Material porque as Escrituras avisam que as necessidades básicas de uma vida humana rica e plena, como abundância material, segurança e paz, justiça social, precisam ser satisfeitas como sinal de que houve salvação. Espiritual porque as Escrituras também afirmam que somente Deus pode intervir em favor das necessidades humanas, e somente nele o ser humano pode encontrar sua verdadeira realização humana. Conforme Arias: "Não há salvação material sem salvação espiritual, nem salvação cristã que ignore a realidade social e material. Assim o testemunha a Bíblia e nossa experiência contemporânea o exige" (ARIAS, 1973, p. 18).

Arias continua dizendo que salvação é um termo rico de sentidos, não se reduzindo a uma ou outra experiência humana apenas. Portanto, é cabível falar em dimensões da salvação. Estas são:

- A salvação que atua na luta pela justiça econômica contra a exploração do homem pelo homem;

- A salvação que atua na luta pela dignidade humana contra a opressão política dos povos;

- A salvação que atua na luta pela solidariedade contra a alienação de algumas pessoas de outras;

- A salvação que atua na luta pela esperança contra o desespero na vida pessoal.

A partir do terceiro capítulo, Mortimer Arias discute a situação do Protestantismo latino-americano sob o binômio: cativeiro-libertação. Para ele, o cativeiro do Protestantismo, na América Latina, é o cativeiro missionário que o impede de se dirigir a seu próprio povo, em suas próprias palavras, desde suas próprias necessidades. Trata-se de um Protestantismo de costas voltadas para a América Latina, enquanto seu rosto está fixado em uma mensagem 
de salvação moldada nos termos de suas matrizes protestantes, nos Estados Unidos e nações europeias. Mais, e pior, essa mensagem é resposta a uma ansiedade, angústia, que pouco tem a ver com aquela dos povos latino-americanos, sendo pouco relevante nas condições do tempo em que eles vivem. Caso os Protestantismos latino-americanos não se libertem desse cativeiro, dificilmente conseguirão anunciar uma mensagem de salvação que seja acolhida na América Latina, porque responsiva às suas carências de salvação.

\section{Salvação nos Protestantismos da Aliança Evangélica Mundial}

Falemos agora da mensagem de salvação elaborada em outro importantíssimo grupo de igrejas protestantes: os evangélicos da Aliança ou Fraternidade Evangélica Mundial (WEF). As questões históricas serão deixadas de lado. Basta apenas dizer que, anteriormente, eles também compunham o Conselho Mundial de Evangelismo e Missão, órgão precursor do CMI, ajudando a fundá-lo, inclusive, nos anos 60 do século passado.

Foi um tempo no qual os agentes protestantes de missão em todo o mundo sentiram a necessidade de reunir esforços e re-discutir a missão nos novos tempos, antes e após as duas guerras mundiais, quando o planeta passou por um duríssimo processo de reorganização com o fim da colonização europeia.

Quando esse Conselho se integrou definitivamente ao CMI, recém-criado, muitos representantes se retiraram por não concordarem com a agenda desse organismo protestante mundial. Estes agora autodenominados "evangélicos" resolveram formar seu próprio organismo, que mantivesse a intenção original das missões protestantes: a proclamação da mensagem de salvação aos povos do mundo. O grande evento que deu visibilidade e autoridade a esse grupo foi o Congresso de Lausanne sobre a Evangelização Mundial, realizado em 1974.

Não é difícil perceber a dificuldade dos protestantes evangélicos com os protestantes ecumênicos acerca da salvação. A seguinte declaração está contida na obra de Mortimer Arias, citando o Dr. M. M. Thomas, diretor do Instituto Cristão para o Estudo da Sociedade, na Índia:

A missão da igreja neste contexto é de estar presente dentro dos movimentos criativos de libertação de nosso tempo, aos quais o próprio Evangelho contribuiu para dar forma, e, de tal maneira participar neles, que sejamos capazes de comunicar o genuíno Evangelho de libertação (ARIAS, 1973, p. 28).

Os protestantes evangélicos, do Pacto de Lausanne, discordarão firmemente dessa interpretação da salvação, e constituirão sua própria mensagem de salvação para o mundo de hoje. O falecido bispo inglês anglicano John 
Stott foi conhecido como uma das principais lideranças dos evangélicos à época. Ele escreveu um livro chamado: John Stott comenta o Pacto de Lausanne. Ele discorre sobre a seguinte afirmação inicial do Pacto: "Ele (o Deus trino) tem chamado do mundo um povo para si, enviando-o novamente ao mundo como seus servos e testemunhas, para estender o seu reino, edificar o corpo de Cristo, e também para a glória do seu nome" (STOTT, 2003, p. 11).

Para Stott, segundo o Pacto de Lausanne, a salvação, quando se trata do povo de Deus, concentra-se na relação da igreja com o mundo, isto é, do povo cristão com o povo não-cristão, ou com a sociedade secular. A esse povo - a Igreja - é enviada a testemunhar, mas não apenas isso, também servir. As duas atividades fazem parte da missão da igreja.

Em outro momento, ele comenta o lugar fundamental que Jesus Cristo ocupa na mensagem de salvação. Ele é o único conteúdo dela, é o único Salvador da humanidade pecadora. Ele também é o Salvador do mundo inteiro, o que quer dizer que ele deve ser proclamado a todo ser humano em todo o mundo, ele é o Salvador universal.

A união entre o propósito de Deus no chamamento de um povo para si e a centralidade de Jesus Cristo leva este povo a compreender sua natureza como evangelizadora. Desde que esta natureza se define por uma ação no mundo, essa se trata de: "proclamar as boas novas de que Jesus Cristo morreu por nossos pecados e ressuscitou assegurando a nossa justificação" (STOTT, 2003, p. 24).

O resultado da evangelização é a salvação do mundo. Esta é sempre atual porque Jesus Cristo está vivo, dando autoridade à proclamação do seu Evangelho, perdoando os pecados dos seres humanos e concedendo o dom do Espírito Santo. O que o ser humano precisa fazer para obter a salvação é arrepender-se e crer, confiando inteiramente em Jesus Cristo como único Salvador.

A evangelização é antecipada pela presença cristã no mundo, uma espécie de prelúdio à proclamação. A presença é uma espécie de diálogo com o mundo, no qual a igreja ouve o mundo com sensibilidade a fim de lhe anunciar o Evangelho. Esta é a grande novidade.

Outra novidade do Pacto de Lausanne consta no artigo sobre a "Responsabilidade Social Cristã”. Uma parte diz o seguinte:

Porque a humanidade foi feita à imagem de Deus, toda pessoa, sem distinção de raça, religião, cor, cultura, classe social, sexo ou idade possui uma dignidade intrínseca em razão da qual deve ser respeitada e servida, e não explorada... Embora a reconciliação com o homem não seja reconciliação com Deus, nem a ação social evangelização, nem a libertação política salvação, afirmamos que a evangelização e o envolvimento sócio-político são ambos parte do nosso dever cristão. Pois ambos são necessárias expressões 
de nossas doutrinas acerca de Deus e do homem, de nosso amor por nosso próximo e de nossa obediência a Jesus Cristo. A mensagem de salvação implica também uma mensagem de juízo sobre toda forma de alienação, de opressão e de discriminação, e não devemos ter medo de denunciar o mal e a injustiça onde quer que existam... A salvação que alegamos possuir deve estar nos transformando na totalidade de nossas responsabilidades pessoais e sociais. A fé sem obras é morta (STOTT, 2003, p. 27-28).

Ao explanar sobre esse artigo, John Stott faz referência à compreensão de salvação elaborada pelo Ecumenismo protestante, um ano antes, em Bangkok. Eles agiram bem ao tentar interpretar a salvação cristã para o homem moderno. Mas, erraram ao equacionar salvação com libertação político-econômica. O Pacto de Lausanne, conforme Stott, tenta manter o conceito tradicional e dogmático da salvação cristã, mas tenta atualizá-lo na inclusão da ação social e política como aspecto ou dimensão da salvação: "Salvação é libertação do mal e, implícito no desejo de Deus de salvar o seu povo do mal, acha-se o juízo sobre o mal de que ele os salva. Além disso, esse mal é tanto social como individual" (STOTT, 2003, p. 30).

O teólogo norte-americano batista, Millard J. Erickson, declara que os protestantes evangélicos, apesar de manterem claros vínculos com suas origens, têm aprofundado o entendimento do pecado e também da salvação para os dias de hoje. No passado, o pecado era uma questão puramente espiritual, de cunho religioso, fruto de uma escolha racional e consciente da pessoa humana. Hoje, tem crescido a aceitação das análises da natureza humana feitas pelas ciências comportamentais, que identificam influências psicológicas e sociais para a explicação da conduta humana, considerada teologicamente pecaminosa. Erickson classifica esse movimento mais abrangente para o entendimento da salvação pelo termo holístico. Ele o descreve assim:

[...] tal holismo é interpretado diferentemente por diferentes grupos de evangélicos. A ênfase cai sobre os benefícios naturais que levam ao evangelho da saúde, riqueza e felicidade. Para outros, o holismo envolve o entendimento de que o pecado não é apenas individual, mas também institucional, racial (em termos de raça humana), e estrutural. Assim, diferentemente de décadas atrás do século vinte, os evangélicos de hoje apreciam a importância das questões associadas com paz, justiça, e outras matérias que tem a ver com a aplicação social do evangelho. Enquanto retém a concepção de que a sociedade não pode ser transformada, finalmente, sem a regeneração dos indivíduos dentro dela, os evangélicos, todavia, tomam a visão de que a ação direta pode ser necessária se as dimensões sociais do pecado devem ser consideradas (ERICKSON, 1995, p. 264).

No terceiro Congresso de Lausanne para a Evangelização Mundial, realizado na cidade de Capetown, África do Sul, no ano de 2010, no "Compromisso da Cidade do Cabo", os protestantes evangélicos reafirmaram sua concepção clássica da salvação como: 
Os seres humanos estão perdidos. A condição básica do ser humano permanece a mesma que foi descrita na Bíblia: estamos em pecado e rebelião, sob o justo julgamento de Deus e, sem Cristo, não temos esperança.

O Evangelho é a boa nova. O Evangelho não é um conceito que precisa de ideias renovadas, mas uma história que precisa ser contada de uma nova maneira. É a história inalterada do que Deus fez para salvar o mundo, essencialmente nos eventos históricos da vida, morte, ressurreição e reino de Jesus Cristo. Em Cristo há esperança.

Por outro lado, o Compromisso usa o termo missão integral para descrever a missão de Deus à qual devem se dedicar os protestantes evangélicos. Segundo o texto:

\begin{abstract}
Missão integral é a proclamação e a demonstração do Evangelho. Não significa simplesmente que o evangelismo e o envolvimento social tenham que ser realizados simultaneamente. Na missão integral, nossa proclamação tem consequências sociais quando convocamos as pessoas ao amor e ao arrependimento em todas as áreas da vida. Nosso compromisso social tem consequências para a evangelização quando damos testemunho da graça transformadora de Jesus Cristo. Se ignoramos o mundo, traímos a palavra de Deus, que nos envia para servir o mundo. Se ignoramos a palavra de Deus não temos nada a oferecer ao mundo (Compromisso da Cidade do Cabo, 55). ${ }^{5}$
\end{abstract}

O que significou o Concílio Vaticano II para o Catolicismo latino-americano, o mesmo foi o Congresso de Lausanne para o Protestantismo evangélico na América latina. O Pacto de Lausanne, seguido do comentário de John Stott, foi fundamental para reorganizar os protestantismos evangélicos na América Latina, nos anos 90 em diante. A orientação fundamental foi manter-se à distância do entendimento de salvação como libertação política e econômica, gestado nos círculos do Protestantismo ecumênico. Ao mesmo tempo, buscou-se ampliar o sentido de salvação para incluir a ansiedade do tempo, vivida entre os povos latino-americanos de então, o que implicava maior atenção às condições sociais e culturais, num esforço de contextualização.

\title{
Salvação Integral: a resposta do Protestantismo evangélico au- tóctone latino-americano
}

Paralelamente ao Pacto de Lausanne, no Protestantismo evangélico autóctone pensante na América Latina gestava-se novo entendimento da salvação, cuja articulação mais original foi realizada por Orlando Costas. Sua contribuição foi uma tentativa de síntese entre os entendimentos ecumênico

\footnotetext{
5 Disponível em: https://www.lausanne.org/pt-br/recursos-multimidia-pt-br/compromisso-da-cidade-do-cabo-pt-br/compromisso\#p1-10). Acesso em: 29 nov. 2018.
} 
e evangélico de salvação, na palestra comunicada no CLADE II (Segundo Congresso Latino-americano de Evangelização), promovido pela Fraternidade Teológica Latino-americana, em 1978, no Peru, realizado quatro anos após o Congresso de Lausanne.

O tema do CLADE II foi: O presente, o futuro e a esperança cristã. E o subtema: Que a América Latina ouça a voz. de Deus. O tema da conferência de Orlando Costas foi: O pecado e a salvação na América Latina. O ponto de partida é o que a Bíblia diz sobre pecado e salvação, para depois descrever a presença de ambos na situação histórica latino-americana, e terminar com indicações sobre como falar de pecado e salvação conforme concretamente demonstrados na América Latina.

Para Costas, a Bíblia não permite falar do pecado como distinto da materialidade humana concreta, senão apenas em termos da afirmação da sua presença e consequências para o ser humano, em suas relações com Deus, com seu próximo e o meio ambiente. Por isso mesmo, o pecado é uma rejeição à palavra que Deus falou e a Deus mesmo, tendo, por consequência, a ira de Deus, que é colocar-se fora do seu amor e experimentar a morte. O pecado também é a injustiça e violência praticadas contra o próximo e a dispersão das potencialidades humanas em um sem-número de ações que o alienam do próximo e da criação. O pecado, ainda, é uma incapacidade de crer, não como uma questão intelectual, mas ética, pois é não se entregar a Deus e ao próximo, ter a si mesmo, e exclusivamente, por medida de todas as coisas, fazendo-se deus para si mesmo e deus para os outros, manipulando a tudo e a todos em favor de si mesmo. Pecado, por fim, é aquilo que se faz contra o outro, não somente a sua negação, mas também a sua educação no mal que se pratica em comum, que se espalha como câncer, que agrega aos demais para que a vontade de um se faça, em que vontades se somam e assumem formas coletivas concretas em leis, costumes, tradições, ideologias, teologias, filosofias e modos de viver, que submetem o ser humano, não lhe deixando alternativa senão o pecado mesmo. O pecado, então, é um problema humano global e social, mas também local e individual.

A salvação deve ser da amplitude do pecado, uma resposta que dê conta dele em suas dimensões todas. A salvação é o resultado do anúncio do Evangelho, pois nele está o poder de Deus para salvar. O conteúdo do Evangelho é o ato criador e redentor de Deus na história de Israel, que se encarna em Jesus Cristo, e se realiza definitivamente na extensão do Reinado de Deus a todos os povos. A salvação, como resultado do Evangelho, tem três sentidos. Primeiro, é obediência ao Reinado de Deus. Sendo indicada pela atenção à Palavra que ele disse, como fruto da graça revelada em Jesus Cristo, e acolhida na fé no Evangelho, um descentrar-se de si mesmo para Deus. 
Segundo, é conseguir um novo senso de justiça, conforme recebido de Deus, e a libertação consequente de toda a culpa, onde ambas, justiça e libertação, são estendidas para abranger o trato com o próximo, por ação daquele que é feito justo e livre, de modo que se opera um descentrar-se de si mesmo para ele. Como diz Costas: "todo movimento que dignifica a vida humana, que promove relações econômicas equitativas e que fomenta a fraternidade entre as pessoas e os povos, é manifestação (ainda que parcial) do poder salvador do Evangelho" (COSTAS, 1969, p. 115).

Terceiro, é a reconciliação com todos e tudo de que o ser humano se alienou por causa do pecado, conduzindo-o à ação proposital e premeditada de buscar e criar a comunhão fraternal no esforço pela paz, pois:

A preocupação e o compromisso com uma vida mais humana, com uma sociedade mais justa e com um meio-ambiente (rios, mar e peixes, ar e aves, terra e animais) mais saudável não são alheios à experiência e à própria esperança da salvação: são parte, parcela da salvação (COSTAS, 1969, p. 116).

A partir da investigação bíblica, como Costas vê historicamente apresentados o pecado e a salvação na América Latina. Nela, o pecado se manifesta desde a conquista realizada pela Europa ibérica e se estende até os dias de hoje, na sua inserção periférica na economia globalizada. Paradoxalmente, também a salvação se manifesta no projeto evangelizador católico e prossegue no "missionarismo" protestante dos séculos XIX e XX. É, então, um lugar cheio de pecado e farto de salvação. Em tal projeto também é notória a idolatria que corrompe, inclusive o cristianismo nela instalado, que projeta um ser humano autocentrado, voltado para si mesmo e que se amplia para todos os mecanismos de opressão e violência conhecidos das sociedades latino-americanas. Por isso mesmo, o sofrimento se mescla com a esperança, sendo esta a melhor interpretação da graça de Deus para a América Latina.

Enfim, como falar de salvação na América Latina? Assumindo as contradições da sua história, seus paradoxos e antagonismos, e fazendo-se a favor do que a salvação significa enquanto obediência a Deus, justiça e libertação, reconciliação e paz. Abandonando as distinções dicotômicas que dividem o pecado entre individual e pessoal, e social e político, indicando que haja uma opção para a salvação em sua manifestação na realidade concreta e material latino-americana. Sendo crítico da maneira como a salvação é revelada por meio do anúncio do Evangelho, seus modos, métodos e conteúdo.

Semelhantemente, outros pensadores evangélicos também se empenharam no entendimento do que significava a salvação na América Latina a partir de reflexões próprias. Elas são melhor percebidas nos documentos finais dos Congressos Latino-americanos de Evangelização (CLADE's). 
Os Congressos representam linhas demarcatórias no desenvolvimento e amadurecimento teológico do pensamento evangélico autóctone ou contextualmente latino-americano. Para eles, convergem as discussões, preocupações e reflexões realizadas fragmentariamente, individualmente, isoladamente, que se conectam e adquirem sentido nos documentos finais. Aqueles produzidos nos CLADE I e II refletem dependência excessiva da herança missionária protestante, pouca maturidade teológica e falta de entrosamento entre as ideias individuais. Todavia, eles preparam para o terceiro CLADE. Seu documento final apresenta um pensamento evangélico autóctone, teologicamente amadurecido e consistente, podendo mesmo ser um programa teológico para a Teologia que se quer evangélica na América Latina.

Nos CLADE I e II, a missão é associada ao mandato de Deus a seu povo para atuar na realidade concreta latino-americana. A proclamação do Evangelho repercute no bem-estar dos povos latino-americanos. Ela é resultado de um entendimento integral de salvação.

O CLADE III amplia e consolida esse entendimento de salvação. Agora, ela está na esfera de uma criação feita por um Deus bom, em comunhão com ela por meio de um pacto de salvação. A entrada do Verbo divino na criação tem em vista a sua redenção e reconciliação, isto é, a retomada do pacto original de salvação e em fidelidade a ele. A vinda de Jesus Cristo, o Verbo feito carne, é um convite ao perdão e reconciliação visando a implantação de novo pacto criacional: o perdoado e reconciliado com Deus expressa sua novidade de vida mudando a relação com os demais seres humanos e toda a criação, agora baseada na prática do amor, verdade e justiça. Com os demais, forma uma comunidade perdoada e reconciliada que estende sua vivência para a realidade concreta da América Latina. A nova representação da salvação, integral, é o Reinado de Deus que se estende como realização do bem-estar intencionado por Deus para sua criação.

\section{Salvação e a sua disposição narrativa}

Uma questão metodológica crítica para a Soteriologia é saber como as histórias amplas, a história de Jesus Cristo e as histórias sobre Jesus Cristo, e a história de alguém, são interconectadas a ponto de vir a existir uma narrativa geradora de salvação.

Conforme Michael Root:

A soteriologia é o momento dentro da reflexão teológica no qual a forma narrativa da mensagem cristã não pode ser evitada. A soteriologia presume dois estados da existência humana, um estado de privação (pecado, corrupção) e um estado de libertação daquela 
privação (salvação, libertação), e um evento que produz uma mudança do primeiro estado para o segundo. Ela presume, então, as condições de uma narrativa: dois estados e um evento que transforma o primeiro estado em um segundo (ROOT, 1986, p. 145).

\section{Padrões narrativos}

Root entende que uma teoria de salvação nada mais é que uma redescrição narrativa da história de Jesus Cristo, implicando sua expansão ou acréscimo, visando torná-la mais clara em seu significado produtor de salvação. A Soteriologia parte de um alvo básico: uma criação na qual Deus, o ser humano e o mundo são colocados em relação, objetivando uma aproximação ao final. Esse é o início e também o final feliz da narrativa de salvação.

Entre o início e o final existe um impedimento. Portanto, há duas possibilidades de o plano ser desenvolvido. Na primeira, o impedimento pode atrasar, mas não impedir a realização do plano. A tensão consiste no quanto e até quando pode prejudicar o plano sem, contudo, afetar definitivamente a sua realização. Na segunda, o impedimento é um desvio fundamental do plano podendo, inclusive, colocar em perigo a sua consumação, caso não seja radical e definitivamente solucionada a tensão que produziu. Nesse caso, o centro da narrativa consiste na tensão e resolução do impedimento, e grande parte da narrativa se concentrará ao redor dessa tensão-solução, pois dela depende o próprio sucesso do plano. Independentemente de quão essencial seja a tensão-solução para o pecado, importa, sim, o evento que possibilita a sua resolução.

Comumente, a narrativa usa padrões já existentes, ou que possam ser criados a partir da realidade vivida, absorvendo para si elementos da história vivida por alguém. Esses padrões são trazidos para dentro do evento, permitindo que a configuração interna ao evento seja exteriorizada nos termos da configuração externa a ele, implicando nova versão dela e criando padrões diferentes para abordá-la.

Se a Soteriologia pode ser desenvolvida como uma narrativa, utilizando padrões já existentes no mundo das pessoas, é a linguagem que lhe dá os meios para expressá-los adequadamente. Podemos falar de uma linguagem soteriológica narrativa (MARROW, 1990). Seu uso requer algumas precauções: o vocabulário não deve ser tomado literalmente, porém metaforicamente, isto é, eles ecoam outras realidades das quais a Soteriologia lança mão para apresentar sua história. Deve-se procurar, nessas realidades, exatamente o(s) ponto(s) no(s) qual(is) se estabeleceu a comparação e, em geral, esta focaliza antes sobre o(s) resultado(s) que a metáfora encerra do que no processo que conduz a ele(s).

Resumindo, uma narrativa soteriológica parte de um plano ao redor de uma criação na qual Deus, o ser humano e o mundo são colocados em rela- 
ção, objetivando uma aproximação final, na qual a armação narrativa auxilia a entender os eventos, localizando-os dentro de padrões mais amplos de significado, mediados pela linguagem, desde a vida e mundo do ouvinte.

\section{Visão de Mundo e Mundo da Vida}

Temos, então, outra questão crítica para a Soteriologia, que é a visão de mundo suposta ou pressuposta na linguagem, e que fornece o mundo da vida do qual se extraem os padrões a serem utilizados nas narrativas de salvação.

Habermas nos ensinou que a visão de mundo, mundivisão ou mundo da vida é um modelo intuitivo que oferece significado à existência humana ao impor ordem ao mundo no qual a pessoa humana vive, às suas experiências nele, e a auxilia a orientar suas ações visando sua conduta nele. Esse modelo é de natureza religiosa e teológica, pois explica a realidade última e final bem como responde à exigência de totalidade de significado da existência humana (HABERMAS, 1990).

Pode-se dizer, pois, que a visão de mundo é um saber acerca de: um horizonte, desde determinada situação de vida, a partir do qual duas pessoas se comunicam; um contexto, desde determinado assunto, sobre o qual ambas as pessoas detêm razoável experiência para se comunicarem; que se apoia, mais profundamente, naquele mundo da vida.

Esse mundo da vida emerge na medida que pessoas dialogam e narram sobre aqueles saberes buscando entender-se sobre algo no mundo, criando uma prática sociocomunicativa que requer a existência de uma cultura, de uma sociedade e de uma estrutura de personalidade. Da cultura, elas extraem os elementos simbólico-semânticos que se encontram difusos em toda a parte. Da sociedade, extraem as normas estabelecidas pelos grupos humanos. Da estrutura da personalidade, extraem as condições peculiares de identidade que se estabelecem em relação ao outro.

Esse processo sociocomunicativo acontece quando emissor e receptor compartilham de uma mesma ou de diferentes visões de mundo utilizando-se da linguagem. Esta, por sua vez, se presta melhor à comunicação de uma visão de mundo quando utilizada na forma de uma narrativa, pois é ela que melhor a explica, descreve ou demonstra, tornando-se elemento-chave em sua construção.

Na compreensão de Nicholas T. Wright:

[...] as estórias que caracterizam a cosmovisão em si são localizadas, no mapa do conhecimento humano, no nível mais fundamental que o das crenças explicitamente formuladas, inclusive crenças teológicas. (...) [cosmovisões] são o estofo básico da existência humana, as lentes através das quais o mundo é visto, a imagem pela qual alguém vive 
nele, e acima de tudo o sentido de identidade e lugar que capacita os seres humanos a ser o que eles são. Ignorar cosmovisões, sejam as nossas ou da cultura que estamos estudando, resultaria em extraordinária superficialidade (WRIGHT, p. 123-124).

Conforme este mesmo autor, há quatro coisas que as cosmovisões fazem, caracteristicamente: proveem estórias a partir das quais os seres humanos enxergam a realidade; dessas estórias, pode-se descobrir como eles lidam com as grandes indagações da existência; estórias e respostas são comunicadas por símbolos culturais; estórias orientam um modo-de-estar-no-mundo, ou uma práxis.

\section{Salvação na América Latina: narrando a Salvação Integral/Shalom}

A descrição de salvação integral, explicitada pelo CLADE III, nos conduz de volta à imagem bíblica do shalom de Deus provido para sua criação. Portanto, retomemos essa imagem, considerando o descanso de Deus no sétimo dia da criação.

No sétimo dia, Deus não descansou apenas de suas obras - a criação de seis dias, mas também convidou a criação ao descanso com ele. O sétimo dia foi o momento do ócio divino e o convite à criação para deliciar-se nele. A satisfação de toda a obra de Deus deveria ser bem gozada na e pela própria obra criada. A falta desse gozo também é a falta do bem-estar, da satisfação e da felicidade, lugares onde a obra criada desfruta os bens do Criador.

Segundo Jürgen Moltmann:

No sábado, a criação chega à sua plenitude. O sábado é a prefiguração do mundo futuro. Se nós, por isso, apresentarmos a criação à luz do seu futuro, da "glória de Deus", da "forma agradável de viver a existência" e da "simpatia geral de todas as coisas", então estamos desenvolvendo uma doutrina sabática da criação. [...] A consumação da criação pela paz sabática diferencia a concepção do mundo como criação da concepção do mundo como natureza, pois a sempre fecunda natureza certamente conhece épocas e ritmos, mas nenhum sábado. É, pois, o sábado que abençoa, santifica e revela o mundo como criação de Deus (MOLTMANN, 1992, p. 23).

O Protestantismo recuperou esse lugar de salvação, chamando-o de graça. Mas, ela foi transmovida para um tempo e lugar a serem usufruídos após as lutas dessa vida aqui, marcadas pela maldição do pecado e sua pérfida herança transmitida à criação divina, que impede o gozo do lugar feliz. Agora, localizado no céu, para além da vida humana na terra. Esta é a salvação lá e depois.

O esforço protestante, na Modernidade ocidental, tem sido por fazer corresponder a salvação a algum tempo terreno, mundano e histórico-social-cultural. Expondo-o como o tempo e lugar da graça, o ser humano o in- 
terpreta como vivendo a salvação por meio da mudança histórica através da transformação das condições de vida. Esta é a salvação aqui e agora.

Entretanto, shalom reflete o gozo da criação após seis dias de trabalho, de obra, de ação. Portanto, a transformação histórica-social-cultural não é salvação, mas meio e sinal para ela. A salvação não se realiza nela, mas lhe dá sentido e propósito. A salvação é o que a transcende para um lugar de perdão, paz, bem-estar, felicidade, e o que pode ser traduzido por essas palavras na palavra principal, que é causa das demais: reconciliação.

Após os seis dias de criação, o mundo, inclusive a humanidade, estava em paz e Deus em paz com ele. O sétimo dia foi a celebração dessa conciliação mundana e cósmica de Deus e sua criação, quando a comunicação entre ambos fluía livre e desimpedida. Um momento específico após a criação, o mais belo e, também, o mais terrível de todos, ocorreu: "Quando ouviram a voz do Senhor Deus, que andava no jardim pela viração do dia, esconderam-se da presença do Senhor Deus, o homem e sua mulher, por entre as árvores do jardim" (Gênesis 3,8).

Trata-se da recusa, da parte de Adão e de Eva, em conversar com o Criador imerso em sua criação, indo até ela na viragem do dia, buscando comunhão, porque conciliado com ela. Como em toda outra situação humana, o despedaçamento do diálogo, da conversa, é precipitar-se no abismo do rompimento, alienação e discórdia. É o começo da guerra. A reconciliação é um apelo de Deus para voltar ao jardim, para retomar a conversa, para que o shalom seja, de novo, a experiência verdadeira da criação.

Esse é o sentido que Paulo quis dar à sua doutrina da reconciliação, quando escolheu o termo grego katalasso (BROWN, 1983b). Sua ênfase no relacionamento pessoal serviu para apontar situações em que algo rompido, quebrado, desfeito, é retomado, consertado ou ligado de novo. Por vezes, Paulo sugere que isso seja feito por meio da colocação de alguma coisa, ou de alguém, de modo a reunir as duas partes rompidas.

A passagem determinante é 2 Coríntios 5,18-19:

Ora, tudo provém de Deus, que nos reconciliou consigo mesmo por meio de Cristo e nos deu o ministério da reconciliação, a saber, que Deus estava em Cristo reconciliando consigo o mundo, não imputando aos homens as suas transgressões, e nos confiou a palavra da reconciliação.

Paulo tornou essa intuição implícita em anúncio explícito de salvação, no qual Jesus Cristo cumpre a função mediadora, isto é, aquele que faz ou estabelece a comunicação, fazendo da reconciliação uma boa nova, o Evangelho. Na cruz, se desenvolveu o drama da salvação humana. De um lado, 
ele fala da parte da humanidade, no seu pecado e culpa e, de outro lado, ele fala da parte de Deus, na oferenda de perdão. O resultado é a reconciliação entre Deus e os seres humanos, e enquanto ele permanecer nessa posição, essa reconciliação permanece para sempre.

Incontornavelmente, o shalom de Deus, sua salvação, passa pelo discurso sobre a forma como a comunicação entre Deus e sua criação é realizada na vida, na morte e na ressurreição de Jesus Cristo. Nele se realiza a vontade salvadora de Deus para a humanidade e o cosmos. Sua história constitui a narrativa que leva a criação, incluída a humanidade inteira, a esperar pela experiência do sábado feliz. Ela é geradora de salvação.

A palavra shalom é tremendamente enriquecida em sua semântica com o acréscimo do sábado da criação. Através dele, percebemos que ela não é apenas paz no sentido da ausência de conflito ou guerra. Trata-se de uma plenitude, mais ainda, uma completude, situação próxima de algo acabado, porque está perfeito, consumado, sem nada a acrescentar. Não é simples resultado da construção humana, porque não é obra e, sim, dom. Não está ao alcance, mas, sim, no horizonte. Não é esforço individual, porém, sim, contribuição pessoal. Não constrói individualidades, todavia, sim, edifica uma comunidade. Não é nem país, nem estado, nem fronteira, nem raça, nem gênero, entretanto, sim, é a conversação entre as partes, provida pelo ato de Jesus Cristo na cruz, para cujo relacionamento ele se torna Tudo no Todo.

\section{Conclusão}

Aprendemos que toda palavra/símbolo requer um objeto, mas é essencial que haja um intérprete que faça a mediação entre seu contexto e a palavra/objeto para que haja sentido no que está sendo dito. Caso contrário, ela não é aproveitável. Aprendemos, com Orlando Costas, que a América Latina é um paradoxo teológico: nascida sob o signo da luta e do conflito, todavia encharcada de esperança provida pelo shalom judaico-cristão e suas muitas traduções nas palavras-símbolos de povos, suas culturas e narrativas, habitantes do lugar.

Da perspectiva da Teologia da Missão Integral, o shalom dá "carne e ossos" para uma narrativa de salvação integral, de modo que a história da América Latina, dos seus povos, dos seus habitantes, segue para seu destino disposto na narrativa das origens, não no retorno para lá, mas na direção de todo bem que nos aguarda. Nesse sentido, não só cabe ter esperança, também é preciso adequar e orientar as narrativas atuais para e por essa esperança.

Assim, não cabe alimentar o conflito como um fim nele mesmo, como se a vida fosse uma eterna luta entre desiguais que, na verdade, são iguais 
em seu ódio e rejeição mútua. Cabe trabalhar o conflito em busca de reconciliação e, quando ela acontece, temos uma pequena amostra do que será o amanhã: quando o shalom for a realização do Reinado de Deus, quando tudo será harmonizado nele, tal como temos visto em Cristo Jesus.

\section{Referências bibliográficas}

ARIAS, Mortimer. Salvação, hoje. Petrópolis: Vozes, 1973.

BAUER, Johannes B. Dicionário bíblico teológico. São Paulo: Loyola, 2000, p. 360, 361.

BROWN, Colin (Ed. Ger.) Dicionário internacional de teologia do Novo Testamento. 1. ed. Vol. IV. São Paulo: Vida Nova, 1983, p. 49-78.

Colin (Ed. Ger.) Dicionário internacional de teologia do Novo Testamento. 1. ed. Vol. III.

São Paulo: Vida Nova, 1983, p. 474-480.

COMPROMISSO DA CIDADE DO CABO. Uma Declaração do que cremos e um chamado para a ação. Terceiro Congresso Lausanne sobre Evangelização Mundial, Cidade do Cabo, 16 a 25 de outubro de 2010, Movimento de Lausanne. Disponível em: https://www. lausanne.org/pt-br/recursos-multimidia-pt-br/compromisso-da-cidade-do-cabo-pt-br/compromisso. Acesso em 29 nov. 2018.

COMTE-SPONVILLE, André. Pequeno tratado das grandes virtudes. São Paulo: Martins Fontes, 1999.

COSTAS, Orlando E. O pecado e a salvação na América Latina. 1969. Coletânea de textos do II Congresso Latino-americano de Evangelização, p. 107-122, Fraternidade Teológica Latino-americana.

DECLARAÇÃO MIQUEIAS SOBRE MISSÃO INTEGRAL. 27 de setembro de 2001, Rede Miqueias. Disponível em: https://www.micahnetwork.org/sites/default/files/doc/ page/mn integral mission declaration portuguese.pdf. Acesso em: 29 nov. 2018.

ERICKSON, Millard J. Evangelical christology and soteriology today. Interpretation, Richmond, vol. 49, n. 3, p. 255-280, 1995.

FEYAERTS, Kurt (Ed.). The Bible through metaphor and translation: a cognitive semantic perspective. Bern: Peter Lang, 2003.

GEORGE, Timothy. Teologia dos reformadores. São Paulo: Vida Nova, 1994.

HABERMAS, Jürgen. Pensamento pós-metafísico. Estudos Filosóficos. Rio de Janeiro: Tempo Brasileiro, 1990.

HAIGHT, Roger. Jesus, símbolo de Deus. São Paulo: Paulus, 2003.

Roger. Dinâmica da teologia. São Paulo: Paulinas, 2004.

MARROW, Stanley B. Principles for interpreting the New Testament soteriological terms. New Testament Studies, Cambridge, vol. 36, n. 2, p. 268-280, 1990.

MOLTMANN, Jürgen. Deus na criação: doutrina ecológica da criação. Petropólis: Vozes, 1992.

NEVILLE, Robert C. Symbols of Jesus: a christology of symbolic engagement. Cambridge: Cambridge University Press, 2001.

RICOEUR, Paul. A bermenêutica bíblica. São Paulo: Loyola, 2006, p. 184-221. 
Paul. A metáfora viva. São Paulo: Loyola, 2000.

ROOT, Michael. The structure narrative of soteriology. Modern Theology, New Jersey, vol. 2, n. 2, p. 145-158, 1986.

SANCHES, Sidney de M. A narrativa como lugar hermenêutico privilegiado para as teologias contextuais latino-americanas. Caminhando, São Bernardo do Campo, vol. 20, n. 1, p. 101-111, 2015.

SLUSSER, Michael. Primitive christian soteriological themes. Theological Studies, California, vol. 44, n. 4, p. 555-569, 1983.

STOTT, John. John Stott comenta o Pacto de Lausanne. Série Lausanne, vol. 2. São Paulo: ABU, 2003.

PINK FLOYD. Talkin' Hawking', disponível em: https://www.vagalume.com.br/pink-floyd/talkin-hawkin.html Acesso em: 06 dez. 2017

WRIGHT, Nicholas T. The New Testament and the people of God. Vol. 1: Christian Origins and the Question of God. London: SPCK, 1992.

Submetido em: 11-12-2017

Aceito em: 19-12-2018 